Research article

\title{
Evaluation of antimicrobial activity of Phellinus linteus (Berk. \& M.A. Curtis.) with their wild collections from Western Ghats of India
}

\author{
Jayashree K. Kodiyalmath* and Krishnappa M. \\ Department of P.G. Studies and research in Applied Botany, Kuvempu University, Shankaraghatta-577451, \\ Shimoga, Karnataka, India
}

*Corresponding Author: jk.kodiyalmath@gmail.com

[Accepted: 27 August 2017]

\begin{abstract}
A survey was conducted in Sagar taluk Shivamogaa district, in the month of June to August 2015 to collect the Phellinus linteus from the wood logs of Jack fruit. The samples were dried and powdered, subjected to extraction using petroleum ether, chloroform and methanol successively by soxhlet method. Extracts were tested for secondary metabolites and showed the presence of alkaloids, phenols, sterols and flavonoids. The sporocarp extract was screened for their antimicrobial activity against different human pathogens like Klebsiella pneumonia, Escherichia coli, Staphylococcus aureus, Candida albicans, Chrysosporium keratinophilum, Pencillium chrysogenum, Aspergillus niger and plant pathogens like Xanthomonas campestris and Agrobacterium tumefaciens using agar well diffusion method. The methanol extracts showed maximum activity followed by chloroform, petroleum ether. The inhibition effects on fungi were low compared to bacteria. GCMS analysis showed the presence of ergosterol. The study reveals that Phellinus linteus showed good antimicrobial activity against Candida albicans and Staphylococcus aureus.
\end{abstract}

Keywords: Phellinus linteus - Sporocarp - Extract - Pathogens - GCMS - Antimicrobial.

[Cite as: Kodiyalmath JK \& Krishnappa M (2017) Evaluation of antimicrobial activity of Phellinus linteus (Berk. \& M.A Curtis.) with their wild collections from Western Ghats of India. Tropical Plant Research 4(2): 351-357]

\section{INTRODUCTION}

Macrofungi are well known for their valuable food and traditional medicines around the world since times. Mushrooms are used as antitumor, antiviral, anti-allergants (Wisitrassameewong et al. 2012) and antiinflammatory (Mourao et al. 2011). Elements from sporocarp and mycelia both contain antimicrobial compounds which can be isolated for the welfare of human beings (Yamac \& Bilgili 2006). Antimicrobial includes antibacterial, antifungal and antiviral (Guler et al. 2009, David et al. 2012). Phellinus Quél. is a potent mushroom as Ganoderma. The secondary metabolites of Phellinus were used to cure gonorrhoea, abdominal pain, stomach ailments and diarrhoea (Sonawane et al. 2012). Few species of Phellinus are tested and proved to be good antimicrobial nature. Phellinus baumii Pilát showed good hypoglycaemic effects against ob/ob mice (Cho et al. 2007). Phellinus are wood inhibiting fungi and may be used as antioxidant and anticancerous (Khatun 2012). Phellinus hartigii (Allesch. \& Schnabl) Pat., P. swieteniae (Murrill) S. Herrera \& Bondartseva, P. merrillii (Murrill) Ryvarden are antimicrobial nature (Altuner \& Akata 2010, Belsare et al. 2010). P. igniarius (L.) Quél. proved good antiviral agent against influenza virus (Song et al. 2014). P. durissimus (Lloyd) A. Roy and P. linteus (Berk. \& M.A. Curtis) shows antioxidant activity (Liang et al. 2009, Lahiri et al. 2010). Out of these all, Phellinus linteus is a medicinal mushroom with a history of about 2000 years of being used for the treatment of haemorrhage, haemostasis and menstruation in China and Korea (Chen et al. 2016). Thus the present work is an attempt to find out the antimicrobial activity of Phellinus linteus (Berk. \& M.A Curtis.) which found in Sagara on the jack fruit (Artocarpus heterophyllus Lam.) tree which prove good antibiotic for the welfare of the human beings. 


\section{MATERIALS AND METHODS}

Sample collection and preparation

The fruiting bodies of Phellinus linteus (Berk. \& M.A Curtis.) are collected from the Sagara taluk, Shivamogga district, during June to August 2015. The major field characters of Phellinus linteus were recorded. The sporocarps were brought to the laboratory and morphological characters were recorded. The samples were oven dried at $45-50^{\circ} \mathrm{C}$. The fruiting bodies were ground to a coarse powder using a mixer. Three hundred grams of the same material was subjected to Soxhlet extraction for $24 \mathrm{hrs}$ each, using $1000 \mathrm{~mL}$ of three solvents, petroleum ether, chloroform and methanol respectively. Secondary metabolites were extracted from sporocarp of Phellinus linteus extracts were dried to powder and kept at $4^{\circ} \mathrm{C}$ (Dulger et al. 2004, Sridhar et al. 2011). These three extracts were screened against different pathogenic fungal and bacterial species by the well diffusion method. The test organisms were collected from the Microbial Type Culture Collection (MTCC), The Institute of Microbial Technology. Chandigarh, India.

Bacteria used to check antibacterial activities

Xanthomonas campestris [MTCC-2286], Pseudomonas syringae [MTCC-1604], Agrobacterium tumefaciens [MTCC-431], Klebsiella pneumonia [MTCC-7028], Escherihia coli [MTCC-1559], Salmonella typhi [MTCC734], Pseudomonas aeruginosa [MTCC-1934], Staphylococcus aureus [MTCC-4734] and Streptomyces pneumoneae [MTCC-4734].

Fungi used to check antifungal activities

Candida albicans [MTCC-1637], Chrysosporium merdarium [MTCC-4608], Trichophyton rubrum [MTCC3272], Chrysosporium keratinophilum [MTCC-1367], Fusarium solani [MTCC-1040], Penicillium chrysogenum [MTCC-947], Aspergillus flavus [MTCC-1783] and Aspergillus niger [MTCC-514].

Preparation of extract

$100 \%=400 \mathrm{mg}$ in $4 \mathrm{ml}$ of DMSO, 50\% $=200 \mathrm{mg}$ in $4 \mathrm{ml}$ of DMSO, 25\% = $100 \mathrm{mg}$ in $4 \mathrm{ml}$ of DMSO.

\section{Agar Well diffusion method}

The antibacterial and antifungal activity of the mushroom extracts were tested using Agar well diffusion method (Sridhar et al. 2011). The culture plates were prepared by inoculating with different bacteria and fungi. Wells were made with $6 \mathrm{~mm}$ cork borer. The wells were loaded with extracts which were dissolved in dimethyl sulfoxide (DMSO) of different concentration (100\%, 50\% and 25\%) using micro pipette. Ciprofloxacin for bacteria, Terbinafine for fungi were used as standard and DMSO was used as control for test microorganisms. The plates were incubated at $27 \pm 2{ }^{\circ} \mathrm{C}$ for $24 \mathrm{hrs}$ for bacterial activity and $48 \mathrm{hrs}$ for fungal activity (Das et al. 2010). The zone formation was observed in plates around the wells and calculated by measuring the diameter of the inhibition zone around. The readings were taken in 4 replicates and the average values were tabulated.

\section{Physicochemical analysis}

a. Determination of Foreign Matter: One gram of sample was weighed and foreign matter was carefully separated. The matter differing in colour and texture were considered as foreign. The separated matter was weighed and subtracted from one gram and percentage was calculated.

b. Determination of Moisture Content: One gram of powder was weighed and dried at $80^{\circ} \mathrm{C}$ for 24 hrs in hot air oven. After $24 \mathrm{hrs}$, the powder was weighed again and the difference in the weight was determined. The percentage of moisture was calculated.

c. Determination of $\mathrm{pH}$ : The $5 \%(\mathrm{w} / \mathrm{v})(5 \mathrm{~g}$ in $100 \mathrm{ml}$ of water) powder was kept on shaker for $5 \mathrm{~h}$ with 140 $\mathrm{rpm}$ and filtered. The filtrate was analysed for the $\mathrm{pH}$ using $\mathrm{pH}$ meter (Elico, India) (Iqbal et al. 2010).

d. Determination of Water Soluble Extractive: Five Grams of powder was weighed and added into a $100 \mathrm{ml}$ conical flask, $25 \mathrm{ml}$ of distilled water is added into to it and kept on a rotator shaker (140 rpm) for 24 hrs. After $24 \mathrm{hrs}$ it was filtered and dried in hot air oven at $80^{\circ} \mathrm{C}$ for $24 \mathrm{hrs}$ and weighed again. The difference in weight was determined and percentage of water soluble extractive were calculated (Gupta 2003).

e. Determination of Alcohol Soluble Extractive: Five grams of powdered material is taken in a $100 \mathrm{ml}$ conical flask, $25 \mathrm{ml}$ of absolute alcohol is added to it and kept on rotator shaker at $140 \mathrm{rpm}$ for $24 \mathrm{hrs}$. After $24 \mathrm{hrs}$ it was filtered and dried in hot air oven set at $80^{\circ} \mathrm{C}$ for $24 \mathrm{hrs}$ and weighed again. The difference in weight was determined and percentage of Alcohol soluble extractive were calculated (Gupta 2003). 
f. Determination of Total Ash Content: The clean and dried silica crucible was weighed, $10 \mathrm{~g}$ of powder was taken and kept in muffle furnace and heated up to $300^{\circ} \mathrm{C}$ for $3-4 \mathrm{hrs}$ until the whole powder turns into ash. The crucible was cooled and weighed again. The difference in the weight was calculated. (Gupta 2003, Indrayan et al. 2005).

g. Determination of Water Soluble Ash: $1 \mathrm{~g}$ of powder was weighed and $10 \mathrm{ml}$ of distilled water is added into it. The mixture was kept on a shaker with $140 \mathrm{rpm}$ for $8 \mathrm{~h}$ and filtered through ash less filter paper. The ash remained in the paper was kept in a crucible (silica) and burnt ash again in a muffle furnace for 3-4 hrs. The weight of ash obtained was noted and percent of water soluble ash was determined (Ahmad \& Sharma 2001).

h. Determination of Acid Insoluble Ash: $1 \mathrm{gm}$ of ash was weighed and $10 \mathrm{ml}$ of distilled water is added into it. The mixture was kept on a shaker with 140rpm for $8 \mathrm{~h}$ and faltered through ash less filter paper. The ash remained in the paper was kept in a crucible (Silica) and burnt to ash again in a muffle furnace for 3-4 hrs. The weight of ash obtained was noted and percentage of acid insoluble ash was determined. (Ahmad \& Sharma 2001).

\section{RESULTS AND DISCUSSION}

Table 1. Result of physicochemical analysis of extract.

\begin{tabular}{lr}
\hline Physicochemical Parameters & $\%$ \\
\hline Foreign Matters & 0.80 \\
Moisture Content & 7.30 \\
Water Soluble Extractive & 8.88 \\
Alcohol Soluble Extractive & 3.20 \\
PH & 6.64 \\
Determination Of Ash & 21.60 \\
Water Soluble Ash & 85.00 \\
Acid Insoluble Ash & 21.00 \\
\hline
\end{tabular}

Physicochemical analysis showed $0.8 \%$ of foreign matter, $7.3 \%$ of moisture content $8.88 \%$ of water soluble extractive, $3.2 \%$ of alcohol soluble extractive; $\mathrm{pH}$ is $6.4,21.6 \%$ of determination of ash, $85 \%$ of water soluble ash and $21 \%$ of acid insoluble ash (Table 1). The extracts were tested for presence of secondary metabolite. Petroleum ether showed the presence of alkaloids and tannins. Chloroform extracts showed positive to alkaloids, tannins, steroids, glycosides and phenols. Methanol showed the presence of flavonoids, glycosides triterpenoids and phenols (Table 2).

Table 2. Phytochemicals test of Phellinus linteus (Berk. \& M.A Curtis.).

\begin{tabular}{lccc}
\hline Tests & Pet, ether & Chloroform & Methanol \\
\hline Alkoloids & + & + & + \\
Saponins & - & - & - \\
Tannins & + & + & + \\
Flavonoids & - & - & + \\
Steroids & - & + & + \\
Glycosides & - & - & + \\
Triterpenoids & - & + & + \\
Phenols & - & + \\
\hline
\end{tabular}

The extracts showed varied antimicrobial result when tested against pathogens tables 2 . The petroleum ether extract inhibited Salmonella typhi and Staphylococcus aureus $(12 \mathrm{~mm})$ at maximum. Agrobacterium tumefaciens, Klebsiella pneumonia, Pseudomonas aeruginosa were $(10 \mathrm{~mm})$ moderately inhibited. Xanthomonas campestris, Pseudomonas syringae, Escherichia coli, Streptomyces pneumoneae were (8-0) least inhibited by petroleum ether extracts. The fungal pathogens like Trichophyton rubrum, Fusarium solani, Aspergillus flavus and Aspergillus niger were completely resistant showing no inhibition whereas Chrysosporium keratinophilum was inhibited maximum that of other test organism. Candida albicans and Chrysosporium merdarium were inhibited moderately.

Chloroform extracts inhibited test organisms better than petroleum ether. K. pneumonia and $S$. aureus were inhibited maximum by showing 16 and $17 \mathrm{~mm}$ zone. The chloroform extract inhibited $P$. syringae, E. coli, $P$. aeruginosa, S. pneumoneae, A. tumefaciens and S. typhi moderately by showing 13-14 mm inhibition zone. Whereas $X$. campestris were least inhibited with $8 \mathrm{~mm}$ (Table 3, Fig. 1). F. solani $(22 \mathrm{~mm}$ ) had the maximum 
effect of chloroform extract followed by A. niger and C. keratinophilum (20 mm). C. merdarium, T. rubrum and P. chrysogenum were moderately affected with $18-19 \mathrm{~mm}$ inhibition zone. A. flavus and C. albicans were least inhibited by chloroform extract (Table 4, Fig. 2).

Table 3. Antibacterial activity of Phellinus linteus (Berk. \& M.A Curtis.) at different concentration and different solvent.

\begin{tabular}{|c|c|c|c|c|c|c|c|c|c|c|c|}
\hline \multirow{3}{*}{ S.N. } & \multirow{3}{*}{$\begin{array}{l}\text { Name of } \\
\text { pathogen }\end{array}$} & \multicolumn{9}{|c|}{ Zone of inhibition in $\mathrm{mm}$} & \multirow{3}{*}{ Standard } \\
\hline & & \multicolumn{3}{|c|}{ Petroleum ether } & \multicolumn{3}{|c|}{ Chloroform } & \multicolumn{3}{|c|}{ Methanol } & \\
\hline & & $100 \%$ & $50 \%$ & $25 \%$ & $100 \%$ & $50 \%$ & $25 \%$ & $100 \%$ & $50 \%$ & $25 \%$ & \\
\hline 1 & $\mathrm{Xc}$ & $08 \pm 0$ & 0 & 0 & $08 \pm 0.5$ & $06 \pm 1.0$ & 0 & $20 \pm 1.0$ & $15 \pm 2.0$ & $09 \pm 1.5$ & $19 \pm 1.0$ \\
\hline 2 & Ps & $08 \pm 0$ & 0 & 0 & $14 \pm 0.6$ & $10 \pm 2.0$ & $7 \pm 1.0$ & $24 \pm 1.5$ & $16 \pm 1.0$ & $10 \pm 1.5$ & $25 \pm 1.0$ \\
\hline 3 & At & $10 \pm 0$ & 0 & 0 & $13 \pm 0.5$ & $10 \pm 1.6$ & $8 \pm 1.0$ & $30 \pm 0.5$ & $24 \pm 1.0$ & $15 \pm 1.0$ & $36 \pm 1.0$ \\
\hline 4 & $\mathrm{Kp}$ & $10 \pm 0$ & 0 & 0 & $16 \pm 1.0$ & $10 \pm 0.7$ & $6 \pm 0.8$ & $25 \pm 2.0$ & $20 \pm 1.5$ & $15 \pm 1.0$ & $28 \pm 2.0$ \\
\hline 5 & Ec & $09 \pm 0$ & 0 & 0 & $15 \pm 1.0$ & $08 \pm 2.0$ & 0 & $24 \pm 1.5$ & $20 \pm 1.5$ & $18 \pm 1.0$ & $24 \pm 2.0$ \\
\hline 6 & St & $12 \pm 0$ & $8 \pm 1$ & 0 & $13 \pm 0.5$ & $10 \pm 1.4$ & $6 \pm 1.0$ & $24 \pm 2.3$ & $20 \pm 1.3$ & $18 \pm 2.0$ & $26 \pm 1.5$ \\
\hline 7 & $\mathrm{~Pa}$ & $10 \pm 0$ & 0 & 0 & $14 \pm 1.0$ & $10 \pm 1.0$ & $8 \pm 1.0$ & $28 \pm 1.2$ & $20 \pm 1.5$ & $10 \pm 2.0$ & $28 \pm 1.0$ \\
\hline 8 & $\mathrm{Sa}$ & $12 \pm 0$ & $8 \pm 1$ & 0 & $17 \pm 0.8$ & $13 \pm 0.7$ & $9 \pm 1.5$ & $28 \pm 2.0$ & $19 \pm 1.5$ & $10 \pm 2.0$ & $30 \pm 1.2$ \\
\hline 9 & $\mathrm{Sp}$ & $08 \pm 0$ & 0 & 0 & $14 \pm 0.8$ & $10 \pm 0.5$ & $6 \pm 1.0$ & $22 \pm 1.2$ & $15 \pm 1.3$ & $9 \pm 1.4$ & $25 \pm 1.0$ \\
\hline
\end{tabular}

Note: Mean of 3 replicates for each concentration; $\mathrm{XC}=$ Xanthomonas campestris, $\mathrm{Ps}=$ Pseudomonas syringae, $\mathrm{At}=$ Agrobacterium tumefaciens, $\mathrm{Kp}=$ Klebsiella pneumonia, $\mathrm{Ec}=$ Escherihia coli, $\mathrm{St}=$ Salmonella typhi, $\mathrm{Pa}=$ Pseudomonas aeruginosa, $\mathrm{Sa}=$ Staphylococcus aureus, $\mathrm{Sp}=$ Streptomyces pneumoneae. .

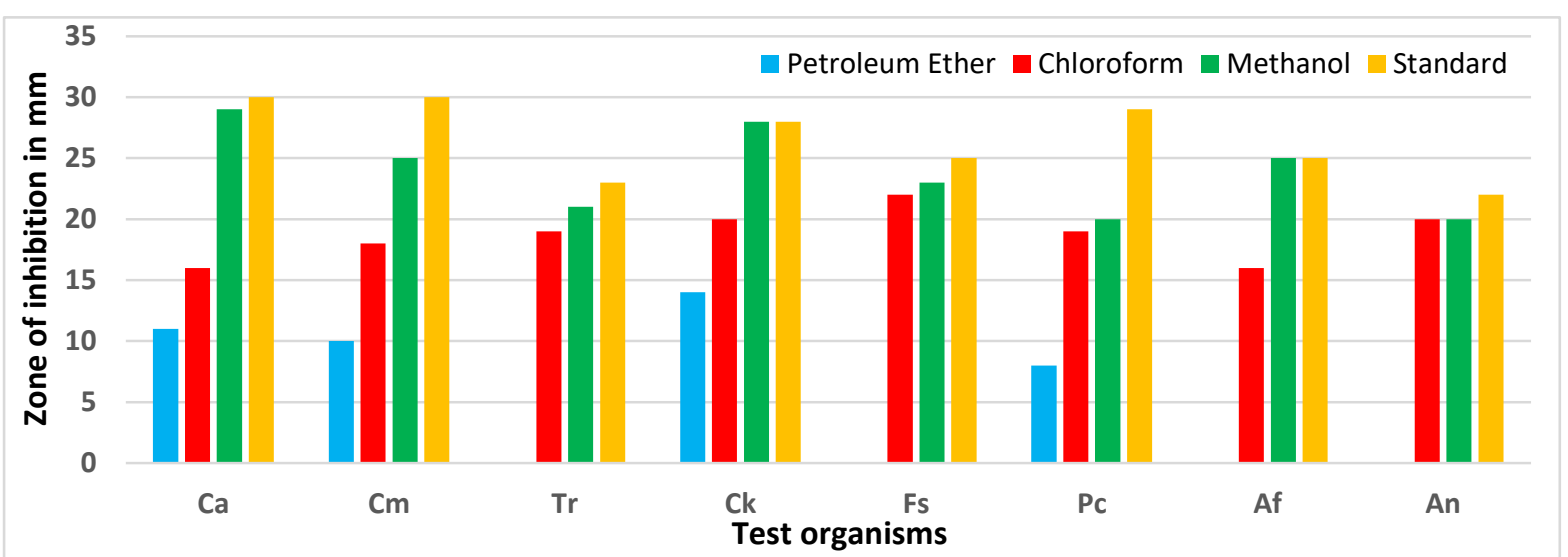

Figure 1. Antifungal activity of Phellinus linteus (Berk. \& M.A Curtis.) at 100\% concentration of different solvent extract. $[\mathrm{Ca}=$ Candida albicans, $\mathrm{Cm}=$ Chrysosporium merdarium, $\mathrm{Tr}=$ Trichophyton rubrum, Ck= Chrysosporium keratinophilum, $\mathrm{Fs}=$ Fusarium solani, $\mathrm{Pc}=$ Penicillium chrysogenum, $\mathrm{Af}=$ Aspergillus flavus, An=Aspergillus niger]

Table 4. Antifungal activity of Phellinus linteus (Berk. \& M.A Curtis.) at different concentration and different solvent.

\begin{tabular}{|c|c|c|c|c|c|c|c|c|c|c|c|}
\hline \multirow{3}{*}{ S.N. } & \multirow{3}{*}{$\begin{array}{c}\text { Name of } \\
\text { pathogens }\end{array}$} & \multicolumn{9}{|c|}{ Zone of inhibition in $\mathbf{m m}$} & \multirow{3}{*}{ Standard } \\
\hline & & \multicolumn{3}{|c|}{ Petroleum ether } & \multicolumn{3}{|c|}{ Chloroform } & \multicolumn{3}{|c|}{ Methanol } & \\
\hline & & $100 \%$ & $50 \%$ & $25 \%$ & $100 \%$ & $\mathbf{5 0 \%}$ & $25 \%$ & $100 \%$ & $50 \%$ & $25 \%$ & \\
\hline 1 & $\mathrm{Ca}$ & $11 \pm 1.6$ & $10 \pm 2.0$ & $08 \pm 1.0$ & $16 \pm 0.0$ & $12 \pm 0.5$ & $10 \pm 0.6$ & $29 \pm 1.5$ & $22 \pm 2.0$ & $19 \pm 1.5$ & $30 \pm 2.3$ \\
\hline 2 & $\mathrm{Cm}$ & $10 \pm 0.0$ & $08 \pm 1.0$ & 0 & $18 \pm 1.0$ & $10 \pm 0.5$ & $08 \pm 0.5$ & $25 \pm 1.5$ & $19 \pm 1.5$ & $15 \pm 1.0$ & $30 \pm 1.0$ \\
\hline 3 & $\operatorname{Tr}$ & 0 & 0 & 0 & $19 \pm 1.2$ & $16 \pm 1.0$ & $14 \pm 0.5$ & $21 \pm 1.0$ & $19 \pm 1.2$ & $14 \pm 0.4$ & $23 \pm 1.2$ \\
\hline 4 & $\mathrm{Ck}$ & $14 \pm 1.0$ & $08 \pm 0.5$ & 0 & $20 \pm 1.3$ & $13 \pm 0.5$ & $06 \pm 0.0$ & $28 \pm 2.0$ & $25 \pm 2.2$ & $20 \pm 1.7$ & $28 \pm 0.5$ \\
\hline 5 & Fs & 0 & 0 & 0 & $22 \pm 1.8$ & $19 \pm 1.8$ & $15 \pm 1.0$ & $23 \pm 1.2$ & $20 \pm 1.7$ & $15 \pm 1.0$ & $25 \pm 1.4$ \\
\hline 6 & $\mathrm{Pc}$ & $08 \pm 2.0$ & $06 \pm 0.5$ & 0 & $19 \pm 0.4$ & $14 \pm 0.5$ & $09 \pm 0.7$ & $20 \pm 1.0$ & $15 \pm 1.0$ & $11 \pm 0.2$ & $29 \pm 1.2$ \\
\hline 7 & Af & 0 & 0 & 0 & $16 \pm 1.0$ & $14 \pm 1.5$ & $12 \pm 0.6$ & $25 \pm 0.5$ & $20 \pm 2.0$ & $15 \pm 1.0$ & $25 \pm 1.0$ \\
\hline 8 & An & 0 & 0 & 0 & $20 \pm 2.2$ & $14 \pm 0.5$ & $08 \pm 0.5$ & $20 \pm 0.5$ & $15 \pm 0.8$ & $10 \pm 0.4$ & $22 \pm 1.1$ \\
\hline
\end{tabular}

Note: Mean of 3 replicates for each concentration; $\mathrm{Ca}=$ Candida albicans, $\mathrm{Cm}=$ Chrysosporium merdarium, $\mathrm{Tr}=$ Trichophyton rubrum, $\mathrm{Ck}=$ Chrysosporium keratinophilum, $\mathrm{Fs}=$ Fusarium solani, $\mathrm{Pc}=$ Penicillium chrysogenum, $\mathrm{Af}=$ Aspergillus flavus, $\mathrm{An}=$ Aspergillus niger.

The GCMS analysis of methanol extract showed the presence of ergosterol. This agrees with the result of (Reis et al. 2014) which is anti-tumor component (Chen et al. 2016). A. tumefaciens S. aureus and $P$. aeruginosa showed more susceptibility to methanol extract followed by K. pneumonia, S. typhi, P. syringae, whereas $X$. campestris was resistant to methanol extract. $C$. keratinophilum and $C$. albicans were maximum inhibited by methanol extracts, almost equal to inhibition zone of standard drug. C. merdarium, F. solani, A. 
flavus showed less susceptibility than the C. keratinophilum and C. albicans but T. rubrum, P. chrysogenum and A. niger were least inhibited by methanol extract compared to another test organism (Table 3 and 4). The relative decrease in the inhibition with the concentration of the extract shows that amount of bioactive components in extracts play an important role in inhibition of pathogens. The number of organisms inhibited decrease with the decrease in concentration of extracts. The observed result of the effectiveness of extracts, methanol proved best and petroleum ether showed less inhibition effect which is favourable with the findings of (Ehssan \& Saadabi 2012). S. aureus and E. coli are inhibited maximum by methanol extract this agrees with the result of (Bala et al. 2011). Sonawane et al. (2012) reported methanol showed better activity than ethyl acetate, in present work methanol showed good result than chloroform. Antifungal activity of extracts was lower compared to bacteria this agrees with the result of Jonathan \& Fasidi (2003, 2005). Oyetayo (2009) studied the effect of ethanol extracts of Termitomyces sp. and Lentinus sp. against C. albicans and S. aureus, ethanol extract showed good inhibition against $C$. albicans but $S$. aureus was inhibited hardly by $8 \mathrm{~mm}$ inhibition zone. Methanol extract showed good inhibition zone for E. coli, S. typhi, P. aeruginosa and S. aureus, this agrees with the result of (Balakumar 2010). When (Iftekhar et al. 2011) worked on the antibacterial activity of Ganoderma lucidum, Auricularia auricula and Pleurotus florida against S. aureus and E. coli none of the three mushroom inhibited E. coli but in present study E. coli is inhibited in all the concentration by all solvent extracts.



Figure 1. Antibacterial activity of Phellinus linteus (Berk. \& M.A Curtis.) at 100\% concentration of different solvent extract. [Xc=Xanthomonas campestris, $\mathrm{Ps}=$ Pseudomonas syringae, At=Agrobacterium tumefaciens, $\mathrm{Kp}=\mathrm{Klebsiella}$ pneumonia, $\mathrm{Ec}=$ Escherihia coli, $\mathrm{St}=$ Salmonella typhi, $\mathrm{Pa}=$ Pseudomonas aeruginosa, $\mathrm{Sa}=$ Staphylococcus aureus, $\mathrm{Sp}=$ Streptomyces pneumoneae $]$

\section{CONCLUSION}

Resistance to a wide variety of antibiotics by pathogens and multiple drug resistant organisms has become a serious threat to growing population, there is a need to find new source of antibiotics which are capable of combating several disease causing pathogens. Mushrooms are such a group of organisms which are rich in useful metabolites so further identification and isolation of different active compounds from varieties of mushroom and commercializing their products is necessary. The finding of present work reveals that Phellinus linteus (Berk. \& M.A. Curtis) proves its powerful antimicrobial activity. Candida albicans and Staphylococcus aureus are significantly inhibited by chloroform and methanol extracts. Further work is required to culture mycelia and extract metabolites from it so that there is no need to wait for the appropriate season for harvesting fruiting bodies, for the extraction of secondary metabolites and other bioprospecting activities.

\section{ACKNOWLEDGEMENTS}

The authors are grateful to chairman department of Applied Botany Shankaraghatta for providing lab facilities. They are also indebted to Dr. Syed Abrar, Guest Lecturer Department of Applied Botany, Kuvempu University for identification of the species. We are also thankful to research scholars, Nandan Patel K.J., Vinu K. and Gourish K.C. from Department of Applied Botany, Kuvempu University notably for his help and support.

\section{REFERENCES}

Ahmad RV \& Sharma RK (2001) Evaluation of drug for standardization. In: Proceedings of WHO training cum-workshop, Pharmaceutical lab for Indian medicine, Ministry of health and family welfare, Govt. of www.tropicalplantresearch.com 
India, Ghaziabad.

Altuner EM \& Akata I (2010) Antimicrobial Ativity of Some Macrofungi Extracts. SAU. Fen Bilimleri Dergisi 14: 45-49.

Bala N, Elijebath A B, Aitken, Fechner N, Cusack A \& Steadman KJ (2011) Evaluvation of Antibacterial Activity of Australian Basidiomycetous Macrofungi Using A High-Throughput 96-Well Plate Assay. Pharmaceutical Biology 49: 492-500.

Balakumar R, Shivaprakasam E, Kavita D, Sridhar S \& Kumar JS (2011) Antibacterial and Antifungal Activity of fruit bodies of Phellinus mushroom extract. International Journal of Bioscience 1: 72-77.

Belsare MH, Bapat GS, Ranadive KR, Vaidya JG \& Deokule SS (2010) In-vitro Susceptibility testing of some Phellinus species against Acinetobacter baumannii from Maharashtra India. Journal of Medicinal Plants Research 4: 1335-1338.

Chen H, Tian T, Miao H \& Zhao (2016) Traditional uses, fermentation, phytohemistry and pharmacology of Phellinus linteus: A Review. Fitoterapia 113: 6-26.

Cho EJ, Hwang HJ, Kim SW, Oh JY, Baek YM, Choi JW, Bae SH \& Yun JW (2007) Hypoglycemic effects of exoploysaccharides produced by mycelial culture of two different mushrooms Tremella fuciformis and Phellinus baumii in ob/ob mice. Applied Microbiology Biotechnology 75: 1257-1265.

Das K, Tiwari RKS \& Shrivastava DK (2010) Techniques for Evaluvation of Medicinal Plants Products as Antimicrobial Aents: Current Methods and Recent Trends. Journal of Medicinal Plants Research 4: 104111.

David OM, Fagbohun ED, Oluyege AO \& Adegbuyi A (2012), Antimicrobial activity and Physicochemical Properties of oils from marofungi. Journal of Yeast and Fungi Research 3: 1-6.

Dulger B, Gonuz A \& Gucin F (2004) Antimicrobial activity of the macrofungus Cantharellus cibarius. Pakistan Journal of Biological Sciences 7: 1535-1539.

Ehssan MHO \& Saadabi AM (2012) Screening of antimicrobial activity of wild mushroom from Khartoum State of Sudan. Microbiology Journal 2: 64-69.

Guler P, Akata I \& Kutluer F (2009) Antifungal activity of Fomitopsis pinicola (Sw.: Fr) Karst and Lactarious vellereus (Pers) Fr. African Journal of Biotechnology 8: 3811-3813.

Gupta AK (2003) Quality standards of Indian medicinal plants. Indian council of medicinal research, India.

Iftekhar AF Md. H, Choudhry ZK, Khan Md. I \& Saleh AA (2011) Comparitive Study of Antimicrobial Activity of Wood-Decay Fungi and Antibiotics. Bangladesh Journal of Pharmacology 6: 14-17.

Indrayan AK, Sharma S, Durgapal D, Kumar N \& Kumar M (2005) Valued plants from Uttaranchal. Current Science 89: 1252-1255.

Iqbal D, Pawar RK \& Sharma RK (2010) Physico-chemical standardization of Butea monosperma (Lam.) Kuntze (Palasha): An ayurvedic drug. International Journal of Pharmaceutical Quality Assurance 2: 49-51.

Jonathan SG \& Fasidi IO (2005) Antimicrobial Activity of some selected Nigerian Mushroom. African Journal of Biomedical Research 8: 133-139.

Jonathan SG \& Fasidi IO (2003) Antimicrobial activity of two Nigerian edible macrofungi-Lycoperdon pusilum (Bat. Ex) and Lyocoperdon giganteum (Pers.). African Journal of Biomedical Research 6: 85-90.

Khatun S, Islam A, Cakilcioglu U \& Chatterjee NC (2012) Research on Mushrooms as a Potential source of Nutraceuticals: A Reviewon Indian Prespective. American Journal of Experimental Agriculture 2: 47-73.

Lahiri SK, Gokani RH, Shukla MD, Modi HA, Santani DD \& Shah MB (2010) Evaluation of Antioxidant Activity of plant-parasitic macrofungus: Phellinus durissimus (Lloyd) Roy. Eurasian Journal of Analytical Chemistry 5: 32-45

Liang CH, Syu JL \& Mau JL (2009) Antioxidant Properties of Solid-State Fermented adlay And Rice By Phellinus linteus. Food chemistry 116: 841-845.

Mourao F, Umeo SH, Benetati M, Berteli D, Lourenco EL, Junior AG, Takemura OS, Linde GA \& Colauto NB (2011) Anti-inflammatory activity of Agaricus blazei in different basidiocarp maturation phases. Food and Agricultural immunology 22: 325-333.

Oyetayo VO (2009) Free Radical Scavenging and Antimicrobial Properties of Extracts of Wild Mushrooms. Brazillian Journal of Microbiology 40: 380-386.

Reis FS, Barros L, Sousa MJ, Martins A \& Ferreira ICFR (2014) Analytical methods applied to the chemical characterization and antioxidant properties of three wild edible mushroom species from northeastern Portugal. Food Analytical Methods 7: 645-652.

www.tropicalplantresearch.com 
Sonawane H, Bhosle S \& Garad S (2012) Antimicrobial activity of some species of Phellinus and Ganoderma sample from Western Ghats of India. International Journal of Pharmaceutical Sciences and Research 3: 1795-1799.

Song AR, Sun XL, Kong C, Zhao C, Qin D, Huang F \& Yang S (2014) Discovery Of A New Sesquiterpenoids from Phellinus ignarius with Antiviral Activity Against Influenza Virus. Archives of Virology 159: 753-760.

Sridhar S, Sivaprakasam E, Balakumar R \& Kavitha D (2011) Evaluation of antibacterial and antifungal activity of Ganoderma Lucidum (Curtis) P. Karst fruit bodies extracts. World Journal of Science and Technology 1: $8-11$.

Wisitrassameewong K, Karunarathan SC, Thongklang N, Zhao R, Callac P, Moukha S, Ferandon C, Chukeatirote E \& Hyde KD (2012) Agaricus subrufesens: A Review. Saudi Journal of Biological Sciences 19: 131-146.

Yamac M \& Bilgili F (2006) Antimicrobial activities of fruit bodies and/ or mycelial cultures of some mushroom isolates. Pharmaceutical Biology 44: 660-667. 